Research article

\title{
MOLECULAR DETECTION OF PSEUDORABIES VIRUS (PrV), PORCINE PARVOVIRUS (PPV) AND PORCINE CIRCOVIRUS 2 (PCV2) IN SWINE IN REPUBLIC OF MONTENEGRO
}

\author{
MIKOVIĆ Radoš*, KNEŽEVIĆ Aleksandra ${ }^{3}$, MILIĆ Nenad ${ }^{2}$, KRNJAIĆ Dejan², \\ RADOJIČIĆ Marina ${ }^{2}$, VELJOVIĆ Ljubiša ${ }^{4}$, MILIĆEVIĆ Vesna ${ }^{4}$, ZORIĆ Andrea ${ }^{2}$, \\ STANOJEVIĆ Maja ${ }^{3}$, NIŠAVIĆ Jakov ${ }^{2}$
}

${ }^{1} \mathrm{PhD}$ student; ${ }^{2}$ Department of Microbiology, Faculty of veterinary medicine University of Belgrade, Bul. Oslobođenja 18, Belgrade, Serbia; ${ }^{3}$ Virology Department, Institute of Microbiology and Immunology, Faculty of Medicine, University of Belgrade, Dr Subotica 8, Belgrade, Serbia, ${ }^{4}$ Scientific Veterinary Institute of Serbia, Vojvode Toze 14, Belgrade, Serbia

(Received 30 December 2015; Accepted 13 June 2016)

The presence of pseudorabies virus $(\mathrm{PrV})$, porcine parvovirus (PPV) and porcine circovirus 2 (PCV2) was examined in sixty samples (spleen and lymph nodes) and thirty samples of sacral ganglia collected from non-vaccinated swine by virus isolation and polymerase chain reaction (PCR). Using PCR method PrV was detected in three samples, PPV in seven samples and six samples were found positive for PCV2. The phylogenetic analysis of the nucleotide sequences of three $\operatorname{PrV}$ isolates identified in this study showed high similarity and significant clustering within the $\operatorname{PrV}$ genotype I strains such as Kaplan and Bartha isolated from pigs in Hungary, strain Becker isolated in USA and strain Kolchis isolated in Greece. The nucleotide sequences of two PPV isolates showed high level of similarity with the strain Challenge isolated from pigs in UK, strain Kresse isolated in USA and strains 77 and LZ isolated in China. The phylogenetic analysis of the nucleotide sequences of two PCV2 isolates showed high level of similarity and significant clustering within genotype PCV2b strains such as NIVS-3, NIVS-5 and NIVS-6 isolated in Serbia, strain 3959 isolated in Austria, strain PM165 isolated from pigs in Brasil, and strain XT2008 isolated in China. The results of our study present the molecular characterization of PrV, PPV and PCV2 identified in swine in Republic of Montenegro. Besides that, these results confirmed that PCR is a very useful method for rapid detection of these viruses in subclinically infected swine.

Key words: pseudorabies virus, porcine parvovirus, porcine circovirus 2, nucleotide sequence, Republic of Montenegro

\section{INTRODUCTION}

Aujeszky's disease is caused by Aujeszky's disease virus (ADV) or pseudorabies virus (PrV), which belongs to the family Herpesviridae, subfamily Alphaherpesvirinae, genus

\footnotetext{
*Corresponding author: e-mail: rados.mikovic@gmail.com
} 
Varicellovirus. $\operatorname{PrV}$ is an enveloped virus with double-stranded DNA genome [1]. Conventional restriction fragment length polymorphism (RFLP) analysis of genomic DNA has allowed differentiation of PRV isolates in four major types and several subtypes. In Europe, wild boar PRV strains mainly belong to genotype I, while in domestic swine both type I and II are found. Type III and type IV PRV strains are restricted to Northern Europe and Asia [2]. The virus primarily affects pigs but it is also known to occasionally occur in cattle, sheep, goats, dogs, cats and wild boars which constitute a reservoir of the virus. Aujeszky's disease is a contagious infection and is mainly transmitted by direct and indirect contact between pigs [3,4].

Aujeszky's disease primarily affects swine, in which a variety of clinical symptoms have been described, such as disorders of the central nervous system (CNS), respiratory system and digestive tract, as well as reproductive disorders [5]. The disease is found worldwide in domestic pigs and in wild boar populations [4]. The standard laboratory methods for diagnosis of PrV are mainly based on viral isolation in cell culture, which is time consuming, and other diagnostic techniques such as conventional polymerase chain reaction (PCR) or real-time PCR $[1,4,6,7]$.

Members of the porcine parvovirus (PPV) species cause widespread infections in swine. They belong to the genus Parvovirus, subfamily Parvovirinae, family Parvoviridae and are among the major etiological agents of reproductive failure in sows. PPV infection of susceptible pregnant sows results in infection of the fetus, inducing reproductive complications characterized by embryonic and fetal death, mummification, stillbirth and delayed return to estrus [8,9]. Porcine parvovirus (PPV) is a small, non - enveloped virus with a minus-polarity, single-stranded DNA genome. The genome of PPV has two large open reading frames (ORFs) which almost entirely cover the genome. The first ORF encodes nonstructural protein NS1 which is necessary for viral DNA replication. The second ORF encodes capsid proteins VP1, VP2, and VP3 with masses of 84, 64, and $60 \mathrm{kDa}$, respectively. Capsid protein VP2 harbors major antigenic domains of PPV which can induce PPV-neutralizing antibodies to neutralize PPV infection and plays a key role in PPV diagnosis and immune prophylaxis [9,10]. Virus isolation in cell culture is laborious and time consuming and it cannot be achieved for all PPV strains. Other diagnostic techniques, such as conventional PCR, multiplex PCR or real-time PCR are widely used in the diagnosis of porcine parvovirus [11-13].

Porcine circovirus 2 (PCV2) is a non-enveloped, single-stranded, circular DNA virus of the genus Circovirus, family Circoviridae. The virus is a causative agent of postweaning multisystemic wasting syndrome (PMWS), is an important emerging viral disease in the swine industry. PMWS is the most common form of porcine circovirus-associated diseases (PCVAD) and is characterized by wasting, decreased weight gain, dyspnea, jaundice and enlarged lymph nodes, as well as degeneration, necrosis of hepatocytes, multifocal lymphohistiocytic pneumonia, lymphocytic depletion and multinucleated giant cell formation [14-16]. Three open reading frames (ORFs - ORF1, ORF2 and ORF3) were recognized in the PCV2 genome [17]. While four genotypes of the virus were identified (PCV2a, PCV2b, PCV2c and PCV2d), only three (PCV2a, PCV2b 
and PCV2d) are currently circulating and display a worldwide distribution [18]. The standard laboratory methods for diagnosis of diseases caused by PCV2 are mainly based on immunohistochemistry and in situ hybridization directly in tissue samples or by real-time qPCR [19]. PCR can be used to detect PCV in tissue samples and also in a broad range of body fluids such as blood, faeces, urine, nasal, ocular and tonsillar swabs and semen. Being fast and highly sensitive PCR presents an alternative method for rapid virus detection [20,21].

The objective of our study was the molecular detection of pseudorabies virus (PrV), porcine parvovirus (PPV) and porcine circovirus 2 (PCV2) in swine in Republic of Montenegro. Furthermore, the nucleotide sequences of identified PrV, PPV and PCV2 were compared with corresponding sequences of the abovementioned viruses available in GenBank database in order to reveal the similarity or differences among them.

\section{MATERIAL AND METHODS}

\section{Samples}

In total, sixty samples (spleen and lymph nodes) and thirty samples of sacral ganglia were collected from non-vaccinated healthy swine (gilts and sows) and from animals with reproductive and respiratory disorders. All animals were reared in extensive livestock farming systems in different districts of Republic of Montenegro.

\section{Viruses}

Strain Ercegovac of Pseudorabies virus (PrV) (provided by Scientific Veterinary Institute of Serbia, Belgrade, Serbia), PPV strain Teen (American Bioresearch, USA) and Reference strain 1010-Stoon of PCV2 (provided by Scientific Veterinary Institute "Novi Sad", Novi Sad, Serbia) were used as positive controls for virus isolation in cell culture and PCR.

\section{Virus isolation}

For isolation of PrV and PPV, PK-15 cell lines were used (IZSBS, Brescia). Clinical samples (spleen tissue, lymph nodes and sacral ganglia) were individually inoculated in 24-well microtiter plates with monolayer of PK-15 cell lines. Each plate was inoculated with $100 \mu \mathrm{l}$ of $10 \%$ samples in PBS and incubated for $1 \mathrm{~h}$ at $37^{\circ} \mathrm{C}$ in an environment with $5 \% \mathrm{CO}_{2}$. After one hour, $500 \mu$ l of minimum essential medium (MEM, Biochrom, Germany) with 2\% fetal calf serum (PAA, Austria) was added. Plates were then incubated in the above mentioned conditions and observed every day for the appearance of cytopathogenic effect of viruses (CPE) for PPV and PrV. Identification of isolated strains of $\operatorname{PrV}$ were confirmed by virus-neutralization test [22]. The identification of isolated strains of PPV was performed by haemagglutination inhibition test (HI test) [23]. 


\section{PCR detection}

The extraction of viral DNA from tissue samples was performed using GeneJet Genomic DNA Purification Kit (Thermo Scientific, USA) according to the manufacturer's instructions. For PCR amplification of the specific part of the PrV genome that encodes $\mathrm{gB}$ glycoprotein of the outer viral envelope the following primers were used: (forward 5-CCTCGTAGTACACGTACCCG-3 and reverse 5-CTGGTGCGAGCTGCAGAACAAG-3 (Metabion International, Germany) [7]. For PCR detection of the specific part of the PPV genome that encodes VP2 protein the following primers were used: (forward 5-CACAGAAGCAACAGCAATTAGG-3 and reverse 5-CTAGCTCTTGTGAAGATGTGG-3 (Metabion International, Germany) [7]. Primers for the specific part of PCV2 genome that encodes ORF1 protein were used for PCR (forward 5-CAGCAACATGCCCAGCAAGAAGAAT-3 and reverse 5-TCGATCACACAGTCTCAGTAG- 3, (Metabion International, Germany) [7]. PCR was done using Dream Taq PCR Master Mix (2x) and Water nuclease free (Thermo Scientific, USA) according to the manufacturer's instructions.

The PCR protocol for the detection of $\mathrm{PrV}$ comprised of primary denaturation at $95^{\circ} \mathrm{C}$ for $4 \mathrm{~min}, 40$ repeated cycles of denaturation at $95^{\circ} \mathrm{C}$ for $30 \mathrm{~s}$, annealing at $58^{\circ} \mathrm{C}$ for $30 \mathrm{~s}$ and $72^{\circ} \mathrm{C}$ for $1 \mathrm{~min}$. The process was finalized with a final elongation at $72^{\circ} \mathrm{C}$ for 10 minutes. The presence of specific 368bp band for $\operatorname{PrV}$ detected by agarose gel electrophoresis was considered as a positive result. PCR protocol for the detection of PPV consisted of primary denaturation at $95^{\circ} \mathrm{C}$ for $4 \mathrm{~min}, 35$ repeated cycles of denaturation at $95^{\circ} \mathrm{C}$ for $30 \mathrm{~s}$, annealing at $55^{\circ} \mathrm{C}$ for $30 \mathrm{~s}$ and $72^{\circ} \mathrm{C}$ for $1 \mathrm{~min}$. The process was finalized with a final elongation at $72^{\circ} \mathrm{C}$ for $10 \mathrm{~min}$. The presence of the specific 203bp band for PPV detected by agarose gel electrophoresis was considered as a positive result. The PCR protocol for the detection of PCV2 comprised of primary denaturation at $95^{\circ} \mathrm{C}$ for $4 \mathrm{~min}, 35$ repeated cycles of denaturation at $95^{\circ} \mathrm{C}$ for $30 \mathrm{~s}$, annealing at $56^{\circ} \mathrm{C}$ for $30 \mathrm{~s}$ and $72^{\circ} \mathrm{C}$ for $1 \mathrm{~min}$. The process was finalized with final elongation at $72^{\circ} \mathrm{C}$ for 10 minutes. The presence of the specific $703 \mathrm{bp}$ band for PCV2 detected by agarose gel electrophoresis was considered as a positive result [7].

\section{PrV, PPV and PCV 2 direct sequencing}

PCR products were purified with QIA quick Purification Kit (Qiagen, Valencia, CA, USA). The purified PCR products were subsequently sequenced with Big Dye Terminator Cycle Sequencing Kit (PE Applied Biosystems, Foster City, CA, USA) using PCR primers as sequencing primers. Direct sequencing of PrV, PPV and PCV2 was performed by Sanger sequencing method. Cycle sequencing protocol comprised of initial denaturation at $96^{\circ} \mathrm{C}$ for $2 \mathrm{~min}$, followed by 40 repeated cycles of denaturation at $96^{\circ} \mathrm{C}$ for $10 \mathrm{~s}$, annealing at $50^{\circ} \mathrm{C}$ for $5 \mathrm{~s}$ and elongation at $60^{\circ} \mathrm{C}$ for 4 $\mathrm{min}$. The products were purified by isopropanol and denatured at $95^{\circ} \mathrm{C}$ for $2 \mathrm{~min}$. The sequencing reactions were analyzed on the ABI Prism 310 Genetic Analyzer (Applied Biosystems). The obtained nucleotide sequences were aligned and compared with 
documented virus sequences available in the GenBank database using BLAST software (http://www.ncbi.nlm.nih.gov/BLAST/). Evolutionary analyses were conducted with MEGA 6 software. The phylogenetic trees for PrV, PPV and PCV2 viral strains were constructed using Neighbor Joining algorithm with 1000 bootstrap replicates. The evolutionary distance was computed using Maximum Composite Likelihood method.

\section{RESULTS}

\section{PCR}

Sixty samples (spleen, lymph nodes) and thirty samples of sacral ganglia were individually examined by PCR method for the presence of PrV. In total, 3 out of 90 samples, two sacral ganglia and one lymph node sample were found positive $(3.33 \%)$.

The same samples, except samples of sacral ganglia, were examined for the presence of PPV and PCV2 using PCR method. A total of seven lymph node samples were positive for the presence of PPV DNA (11.66\%). Six lymph node samples were positive for PCV2 DNA (10\%). One lymph node sample was positive for both $\operatorname{PrV}$ and PPV, and two lymph node samples were positive for PPV and PCV2.

PrV and PPV viruses in inoculated cell lines were not observed.

\section{PrV, PPV and PCV2 direct sequencing}

The phylogenetic analysis of the nucleotide sequences of three $\operatorname{PrV}$ isolates identified in this study showed high similarity and significant clustering within $\operatorname{PrV}$ genotype I strains such as Kaplan and Bartha isolated from pigs in Hungary, strain Becker isolated from pigs in USA and strain Kolchis isolated in Greece. PrV genotype II strains such as strains HNQX-China-2012, HNZK-China-2012 and strains JS-2012, HeN1 and TJ isolated in China cluster as a separate branch (Fig. 1). In our investigation, the nucleotide sequences of all seven PPV isolates were identical. The nucleotide sequences of two PPV isolates that were included in phylogenetic typing showed a high level of similarity with the strain Challenge isolated from pigs in UK, strain Kresse isolated from pigs in USA and strains 77 and LZ isolated from pigs in China. US strain NADL2 and VRI-1 strain isolated in South Korea branched separately in the phylogenetic tree indicating a significant level of difference between those strains and PPV isolates obtained in our investigation (Fig. 2). In our investigation, the nucleotide sequences of all six PCV2 isolates were identical. The phylogenetic analysis of the nucleotide sequences of two PCV2 isolates included in phylogenetic typing showed a high level of similarity and significant clustering within genotype PCV2b strains such as NIVS-3, NIVS-5 and NIVS-6 isolated in Serbia, strain 3959 isolated in Austria, strain PM165 isolated from pigs in Brasil, and strain XT2008 isolated in China (Fig 3). 


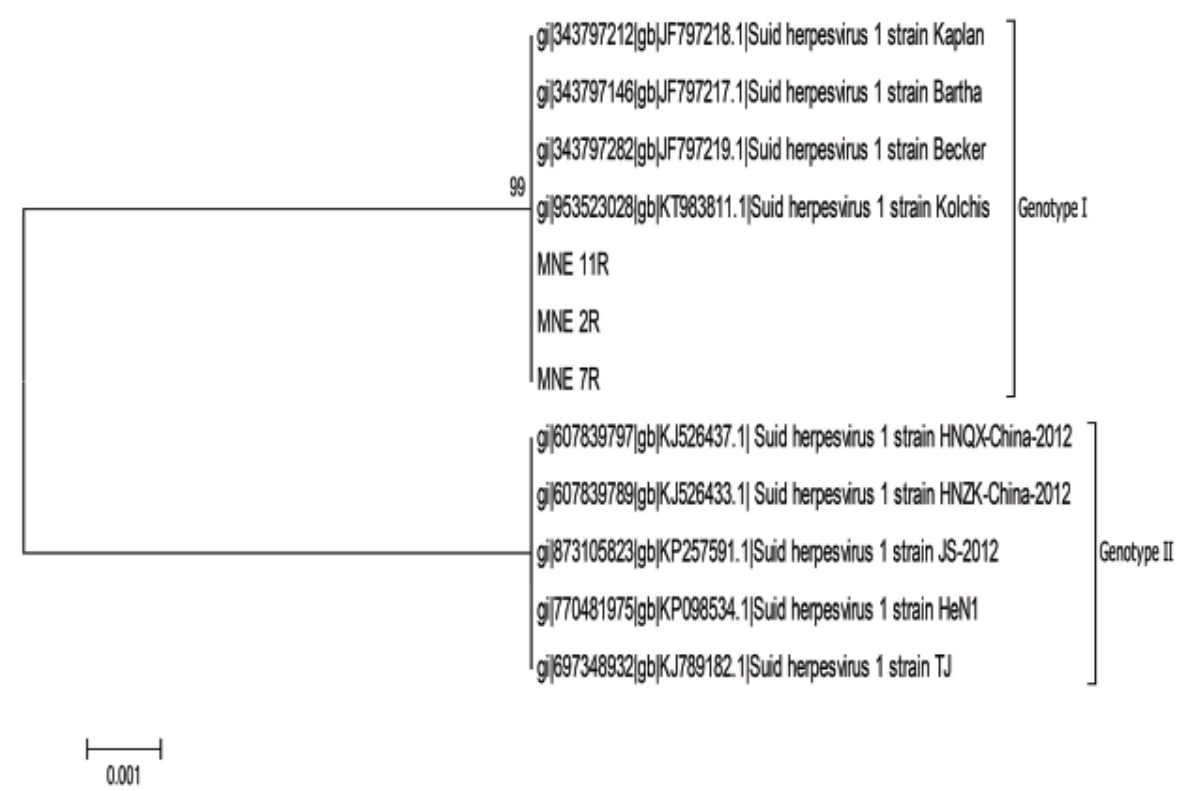

Figure 1. Evolutionary relationships of $\operatorname{PrV}$

Evolutionary analyses were conducted in MEGA 6 software. The tree was constructed using Neighbor Joining algorithm with 1000 bootstrap replicates. The evolutionary distances were computed using Maximum Composite Likelihood method.

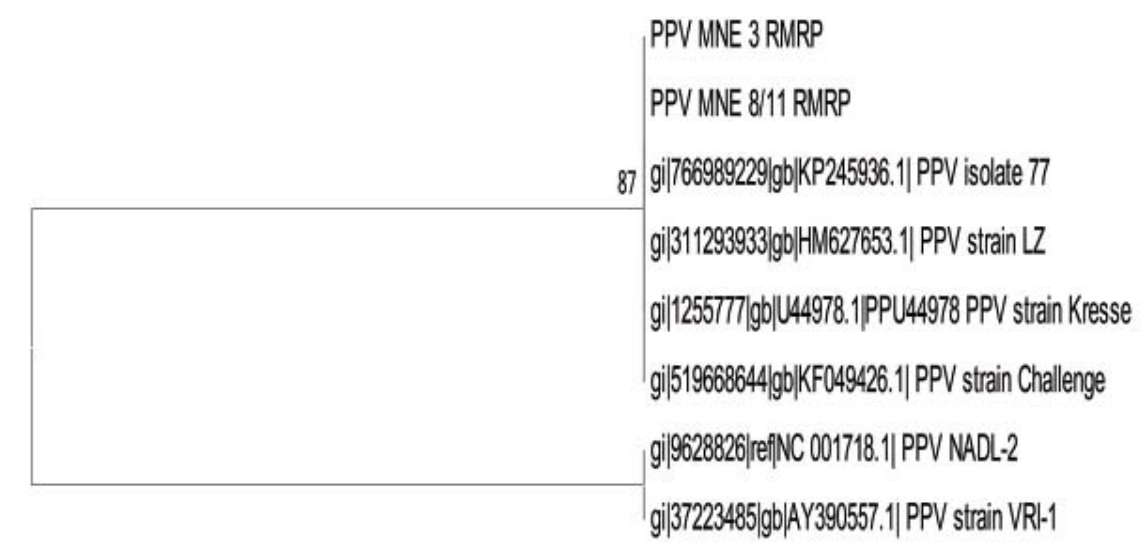

0.001

Figure 2. Evolutionary relationships of PPV

Evolutionary analyses were conducted in MEGA 6 software. The tree was constructed using Neighbor Joining algorithm with 1000 bootstrap replicates. The evolutionary distances were computed using Maximum Composite Likelihood method. 


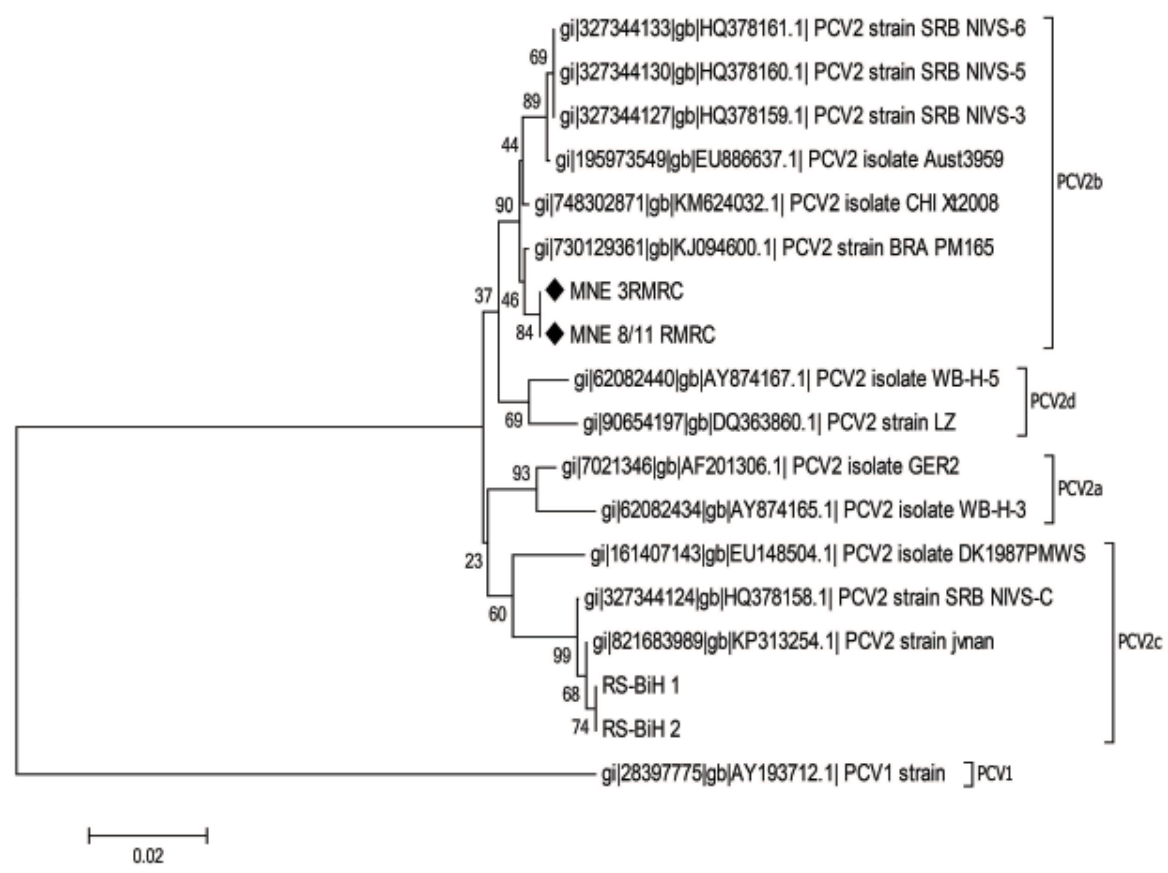

Figure 3. Evolutionary relationships of PCV2

Evolutionary analyses were conducted in MEGA 6 software. The tree was constructed using Neighbor Joining algorithm with 1000 bootstrap replicates. The evolutionary distances were computed using Maximum Composite Likelihood method.

\section{DISCUSSION}

Bascunana et al. [24] investigated the presence of $\operatorname{PrV}$ in different clinical samples using virus isolation and PCR method. Pseudorabies virus (PrV) was not isolated from any sample, however, in 25 organs, the PCR yielded positive results mostly in the trigeminal ganglia and olfactory bulb and less frequently in the tonsils and in the brain. Huang et al. [6] used multiplex PCR for rapid detection of pseudorabies virus, porcine parvovirus and porcine circoviruses 1 and 2 in 58 clinical samples of swine. A PCV2 infection was demonstrated in 51.7\% of samples and a PCV1 infection in $3.4 \%$ of samples. PrV infection was revealed in $1.7 \%$ of samples, PCV1/PCV2 mixed infection was detected in $13.8 \%$ of samples, and PCV2/PrV mixed infection in 10.3\% of samples. PCV2/PPV mixed infection was detected in $5.1 \%$ of samples. Savić et al. [25] detected PCV2/PRRSV co-infection in 50 of 235 samples of swine from ten farms. Here it should be emphasized that porcine reproductive and respiratory syndrome caused by PRRS virus is the most economically important viral disease in the swine industry worldwide [26]. Jiang et al. [12] used multiplex PCR for the detection of PCV2, classical swine fever virus (CSFV), PPV and porcine reproductive and respiratory syndrome virus (PRRS) in seventy-six clinical specimens. PCV2 was 
identified using primers for ORF1 region in $9.2 \%$ of samples and PPV in $3.9 \%$ of samples. Co-infections with these two viruses were identified in $2.6 \%$ of samples. In our investigation, using the PCR method, the presence of PrV was detected in three samples from two different animals (3.33\%), PCV2 in six samples (10\%) and PPV in seven samples (11.66\%). A PPV/PrV mixed infection was revealed in only one sample and PPV/PCV2 mixed infection was detected in two samples. PrV and PPV viruses were not isolated by virus isolation method. In the case of $\operatorname{PrV}$ and PPV, the results of our examination confirmed the presence of latent infection in swine which is in correlation with the results of Miao et al. [27]. Our results confirmed that PCR is a very useful method for the detection of latent PrV and PPV infections in swine, without isolation of the viruses in cell culture. In Europe, wild boar PrV strains are mainly genotype I, while in domestic swine both type I and II are found. Type III and type IV PRV strains are restricted to Northern Europe and Asia [2]. Serena et al. [28] compared nucleotide sequences of Argentinean PrV isolates with the nucleotide sequences of $\operatorname{PrV}$ reference strains available at GenBank. A high percentage of nucleotide similarity was demonstrated between genotype I Argentinean strains (CL/7, CL/15, TL/92 and A/94) and the American strains Rice and Becker. The other genotype I Argentinean strains (CL/96, CL/98, CLP/98-10P and RC/79) had $99.7 \%$ identity with the reference strains Becker and Rice. Also the Argentinean genotype I strains showed high similarity with Brazilian genotype I strains (99.0- 99.4). Verpoest et al. [2] performed molecular characterization of Belgian pseudorabies virus isolates from domestic swine and wild boar. One isolate from domestic pig had a sequence identical to the Kaplan reference strain of PrV. The phylogenetic analysis of the nucleotide sequences of three PrV isolates identified in our study showed high similarity and significant clustering within PrV genotype I strains such as Kaplan and Bartha isolated from pigs in Hungary, strain Becker isolated from pigs in USA and strain Kolchis isolated in Greece. PrV genotype II strains such as However, strains HNQX-China-2012, HNZK-China-2012 and strains JS-2012, HeN1 and TJ isolated in China cluster as a separate branch.

Here it must be emphasized that there is a limited number of PPV nucleotide sequences available at GenBank. Xu et al. [9] compared the nucleotide sequence of the VP2 gene of the PPV NE/09 strain and other PPV strains in China. The obtained results revealed that the VP2 gene of the PPV-NE/09 strain had high sequence similarity with other PPV isolates. The results showed that according to the phylogenetic relationship of the VP2 gene of PPV-NE/09, the isolate was a new mutant strain of PPV prevailing in China. In our investigation, the nucleotide sequences of all seven PPV isolates were identical. The nucleotide sequences of two PPV isolates, that were included in phylogenetic typing showed a high level of similarity with the strain Challenge isolated from pigs in UK, strain Kresse isolated from pigs in USA and strains 77 and LZ isolated from pigs in China. Strain NADL2 isolated from pigs in US and VRI-1 strain isolated in South Korea branched separately in the phylogenetic 
tree indicating a significant level of difference between those strains and PPV isolates obtained in our investigation.

While four genotypes of the virus were identified (PCV2a, PCV2b, PCV2c and PCV2d), only three (PCV2a, PCV2b and PCV2d) are currently circulating and display a worldwide distribution [18]. Molecular analysis of PCV2 strains from Uruguay was done by Ramos et al. [29]. The molecular analysis of the PCV2 cap gene showed a nucleotide similarity of $99.7 \%$ among Uruguayan isolates and two Brazilian isolates included in this study. Phylogenetic analysis revealed that Uruguayan PCV2 strain belongs to PCV2a genotype. In our investigation, the nucleotide sequences of all six PCV2 isolates were identical. The phylogenetic analysis of the nucleotide sequences of two PCV2 isolates included in phylogenetic typing, showed a high level of similarity and significant clustering within genotype PCV2b strains such as NIVS-3, NIVS-5 and NIVS-6 isolated in Serbia, strain 3959 isolated in Austria, strain PM165 isolated from pigs in Brasil, and strain XT2008 isolated in China.

Of note, to the best of our knowledge, the presented data represents the first report of the presence and molecular characterization of PrV, PCV2 and PPV in swine in Republic of Montenegro. Having in mind that there is no sufficient data related to molecular characteristics of PrV, PPV and PCV2 strains in our region, the results obtained in this study are very significant. The results of our investigation show that PCR is a very useful method for rapid, precise and reliable detection of aforementioned viruses, especially in subclinically infected swine which is very important considering the significant economic losses in swine husbandry due to these pathogens in Europe every year.

\section{Acknowledgments}

This study was supported by the Ministry of Education, Science and Technological Development of the Republic of Serbia (grant no. 31008 and 175024).

\section{Authors' contributions}

NJ, MR and ZA participated in design of study and carryed out the molecular diagnostics studies and drafted the manuscript. MR collected samples for analysis. LjV and MV carried out the virology examination. KA, MS, MR and NJ carried out the molecular genetic studies, participated in the sequence and drafted manuscript. $\mathrm{MN}, \mathrm{KD}$ and $\mathrm{RM}$ pariticipated in coordination and helped to draft the manuscript. All authors read and approved the final manuscript.

\section{Declaration of conflicting interests}

The author(s) declared no potential conflicts of interest with respect to the research, authorship, and/or publication of this article. 


\section{REFERENCES}

1. Wernike K, Beer M, Freuling CM, Klupp B, Mettenleiter TC, Müllerb T, Hoffmann B: Molecular double-check strategy for the identification and characterization of Suid herpesvirus 1. Journal of Virological method 2014, 209:110-115.

2. Verpoest S, Cay AB, Regge ND: Molecular characterization of Belgian pseudorabies virus isolates from domestic swine and wild boar. Veterinary Microbiology, 2014, 172:72-77.

3. Moreno A, Sozzi E, Grilli G, Gibelli LR, Gelmetti D, Lelli D, Chiari M, Prati P, Alborali GL, Boniotti MB, Lavazza A, Cordioli P: Detection and molecular analysis of Pseudorabies virus strains isolated from dogs and a wild boar in Italy. Veterinary Microbiology 2015, 177: 359-365.

4. Pol F, Deblanc C, Oger A, Le Dimna M, Simon G, Le Potier MF: Validation of a commercial real-time PCR kit for specific and sensitive detection of Pseudorabies. Journal of Virological Methods 2013, 187: 421-423.

5. Steinrigl A, Revilla-Fernandez S, Kolodziejek J, Wodaka E, Bago Z, Nowotny N, Schmoll F, Kofer J: Detection and molecular characterization of Suid herpesvirus type 1 in Austrian wild boar and hunting dogs. Veterinary Microbiology 2012, 157:276-284.

6. Huang C, Hung J, Wu C, Chien M: Multiplex PCR for rapid detection of pseudorabies virus, porcine parvovirus and porcine circoviruses. Veterinary Microbiology 2004, 101: 209-214.

7. Ogawa H, Taira O, Hirai T, Takeuchi H, Nagao A, Ishikawa Y, Tuchiya K, Nunoya T, Ueda S: Multiplex PCR and multiplex RT-PCR for inclusive detection of major swine DNA and RNA viruses in pigs with multiple infections. Journal of Virological Methods 2009, 160:210-214.

8. Cadar D, Dan A, Tombacz K, Lorincz M, Kiss T, Becskei Z, Spinua M, Tuboly T, Csagola A: Phylogeny and evolutionary genetics of porcine parvovirus in wild boars. Infection, Genetics and Evolution 2012, 12:1163-1171.

9. Xu YG, Cui LC, Wang HW, Huo GC, Li SL: Characterization of the capsid protein VP2 gene of a virulent strain NE/09 of porcine parvovirus isolated in China. Research in Veterinary Science 2013, 94:219-224

10. Zheng L, WangY, Li M, Chen H, Guob X, Genga J, Wang Z, Weia Z, Cui B: Simultaneous detection of porcine parvovirus and porcine circovirus type 2 by duplex real-time PCR and amplicon melting curve analysis using SYBR Green. Journal of Virological Methods 2013, 187:15-19.

11. Dias AS, Gerber PF, Araujo AS, Auler PA, Gallinari GC, Lobato ZIP: Lack of antibody protection against Porcine circovirus 2 and Porcine parvovirus in naturally infected dams and their offspring. Research in Veterinary Science 2013, 94:341-345.

12. Jiang Y, Shang H, Xu H, Zhu L, Chen W, Zhao L, Fang L: Simultaneous detection of porcine circovirus type 2, classical swine fever virus, porcine parvovirus and porcine reproductive and respiratory syndrome virus in pigs by multiplex polymerase chain reaction. The Veterinary Journal 2010, 183:172-175.

13. Wilhelm S, Zimmermann P, Selbitz HJ, Truyen U: Real-time PCR protocol for the detection of porcine parvovirus in field samples. Journal of Virological Methods 2006, 134: 257-260.

14. Kim YH, Kweon CH, Kang SW, Oha KI, Song JY, Lee KK, Park SC: Vero cells expressing porcine circovirus type 2-capsid protein and their diagnostic application. Journal of Virological Methods 2013, 194:26-32.

15. Chang CY, Deng MC, Wang F, Tsai H, Yang C, Chang C, Huang Y: The application of a duplex reverse transcription real-time PCR for the surveillance of porcine reproductive and 
respiratory syndrome virus and porcine circovirus type 2. Journal of Virological Methods 2014, 201:13-19.

16. Krakowka S, Allan G, Ellis J, Hambergd A, Charreyre C, Kaufmann E, Brooks C, Meehan B: A nine-base nucleotide sequence in the porcine circovirus type 2 (PCV2) nucleocapsid gene determines viral replication and virulence. Virus Research 2012, 164:90-99.

17. Wei C, Zhang M, Chen Y, Xie J, Huang Z, Zhu W, Xu T, Cao Z, Zhou P, Su S, Zhang G: Genetic evolution and phylogenetic analysis of porcine circovirus type 2 infections in southern China from 2011 to 2012. Infection, Genetic and Evolution 2013, 17:87-92.

18. Franzo G, Cortey M, de Castro AMMG, Piovezan U, Szabo MPJ, Drigo M, Segales J, Richtzenhain LJ: Genetic characterization of Porcine cicovirus type 2 (PCV2) strains from feral pigs in the Brazilian Pantanal: An opportunity to reconstruct the history of PCV2 evolution. Veterinary Microbiology 2015, 178:158-162.

19. Becskei Z, Aleksić - Kovačević S, Rusvai M, Balka G, Jakab C, Petrović T, Knežević M: Distribution of porcine circovirus 2 Cap antigen in the lymphoid tissue of pigs affected by postweaning multisystemic wasting syndrome. Acta Veterinaria Hungarica 2010, 58:483498.

20. Caprioli A, McNeilly F, McNair I, Lagan-Tregaskis P, J. Ellis, Krakowka S, McKillen J, Ostanello F, Allan G: PCR detection of porcine circovirus type 2 (PCV2) DNA in blood, tonsillar and faecal swabs from experimentally infected pigs. Research in Veterinary Science 2006, 81:287-292.

21. Liu JK, Wei CH, Yang XY, Dai AL, Xiao-Hua L: Multiplex PCR for the simultaneous detection of porcine reproductive and respiratory syndrome virus, classical swine fever virus, and porcine circovirus in pigs. Molecular and Cellular Probes 2013, 27:149-152.

22. Capua RF, Banks M, Tamba M, Calzetta G: Isolation and characterisation of an Aujeszky's disease virus naturally infecting a wild boar (Sus scrofa). Veterinary Microbiology 1997, 55:141-146.

23. Nišavić J, Milić N: Examination of the activity of glycoprotein $\mathrm{HN}$ and $\mathrm{F}$ antigens of outer envelope of the parainfluenza virus type 3 by using fusional, hemolytic and hemagglutinating test, in vitro. Acta Veterinaria 2006, 56:431-436.

24. Ros Bascunana C, Bjijrnerot L, Ballagi-Pordhy A, Robertsson JA, Belak S: Detection of pseudorabies virus genomic sequences in apparently uninfected 'single reactor pigs. Veterinary Microbiology 1997, 55:37-47.

25. Savić B, Radanović $\mathrm{O}$, Jovičić D, Nešić K, Ivanović S, Stevančević $\mathrm{O}$, Cvetojević Đ, Kasagić D:Survey of infectious agents associated with porcine respiratory disease complex (PRDC) in Serbian swine herds using polymerase chain reaction (PCR) detection. Acta Veterinaria 2015, 65:79-88.

26. Karniychuk U, Nauwynck JH: Performance of assays for testing antibodies against porcine reproductive and respiratory syndrome virus in sera collected from swine farms in a region with an extreme virus heterogeneity. Acta Veterinaria 2014, 64:44-51.

27. Miao L, Zhang C, Chen C, Cui S: Real-time PCR to detect and analyze virulent PPV loads in artificially challenged sows and their fetuses. Veterinary Microbiology 2009, 138, 145-149.

28. Serena MS, Metza GE, Mortola EC, Echeverria MG: Phylogenetic analysis of Suid Herpesvirus 1 isolates from Argentina. Veterinary Microbiology 2011, 154:78-85.

29. Ramos N, Mirazo S, Castro G, Arbiza J: Molecular analysis of Porcine Circovirus Type 2 strains from Uruguay: Evidence for natural occurring recombination. Infection Genetics and Evolution 2013, 19:23-31. 


\title{
MOLEKULARNA DETEKCIJA PrV, PPV i PCV2 KOD SVINJA U REPUBLICI CRNOJ GORI
}

\author{
MIKOVIĆ Radoš, KNEŽEVIĆ Aleksandra, MILIĆ Nenad, KRNJAIĆ Dejan, \\ RADOJIČIĆ Marina, VELJOVIĆ Ljubiša, MILIĆEVIĆ Vesna, ZORIĆ Andrea, \\ STANOJEVIĆ Maja, NIŠAVIĆ Jakov
}

Primenom metode izolacije virusa i PCR metode, ukupno je ispitano devedeset uzoraka poreklom od svinja iz ekstenzivnog uzgoja iz različitih delova Crne Gore na prisustvo pseudorabijes virusa svinja (PrV), parvovirusa svinja (PPV) i svinjskog cirkovirusa 2 (PCV2). Primenom PCR metode prisustvo PrV je ustanovljeno kod tri uzorka, PPV kod sedam uzoraka, dok je prisustvo PCV2 utvrđeno kod šest uzoraka poreklom od svinja. Nukleotidne sekvence tri izolata PrV utvrđene u uzorcima poreklom od svinja koje su bile uključene u filogenetsku analizu su pokazale visok stepen sličnosti sa nukleotidnim sekvencama sojeva Kaplan i Bartha virusa izolovanih u Mađarskoj, zatim sa sekvencom soja Becker izolovanog u SAD-u i sekvencom soja Kolchis izolovanog u uzorcima poreklom od svinja u Grčkoj. Sva tri izolata su pripadala genotipu I pseudorabijes virusa. Nukleotidne sekvence dva izolata parvovirusa svinja su pokazale visok stepen sličnosti sa sekvencom soja Challenge izolovanog kod svinja u Velikoj Britaniji, zatim sekvencama soja Kresse izolovanog kod svinja u SAD-u i sojeva 77 i LZ izolovanih kod svinja u Kini. Filogenetska analiza nukleotidnih sekvenci dva PCV2 izolata je pokazala visok stepen sličnosti sa sojevima genotipa PCV2b kao što su NIVS-3, NIVS-5 i NIVS-6 izolovanim u Srbiji, sojem 3959 virusa izolovanim u Austriji i sojem PM165 virusa izolovanim u Brazilu i sojem XT2008 virusa izolovanim u Kini. Dobijeni rezultati ispitivanja pružili su uvid u molekularnu karakterizaciju sojeva virusa Aujeckijeve bolesti, svinjskog parvovirusa i svinjskog cirkovirusa 2 identifikovanih kod svinja u Crnoj Gori. Pored toga, dobijeni rezultati ispitivanja su potvrdili opravdanost korišćenja metode PCR u brzoj i pouzdanoj detekciji prethodno navedenih virusa kod supklinički inficiranih svinja. 